\title{
Gene expression profile of cancer stem-like cells in the SW480 colon adenocarcinoma cell line
}

\author{
YUANYUAN WANG ${ }^{1,2^{*}}$, LING ZHOU ${ }^{1 *}$, QING QING ${ }^{2,3}$, YINGFEI LI $^{4}$, \\ LIXUAN $\mathrm{LI}^{2}$, XIAOYING DONG ${ }^{1}$ and BING XIAO ${ }^{2}$ \\ ${ }^{1}$ Department of Oncology, ${ }^{2}$ Guangdong Provincial Key Laboratory of Gastroenterology, \\ Department of Gastroenterology, Nanfang Hospital, Southern Medical University, Guangzhou, Guangdong 510515; \\ ${ }^{3}$ Department of Gastroenterology, The Third Affiliated Hospital of Guangzhou Medical University, \\ Guangzhou, Guangdong 510260; ${ }^{4}$ Guangdong Provincial Key Laboratory of Digestive Disease, \\ Department of Gastroenterology and Hepatology, Guangzhou First Municipal People's Hospital, \\ Guangzhou Medical University, Guangzhou, Guangdong 510180, P.R. China
}

Received June 17, 2018; Accepted April 22, 2019

DOI: $10.3892 / o r .2019 .7146$

\begin{abstract}
Cancer stem cells (CSCs) serve an important role in tumorigenesis, tolerance to treatment, relapse and metastasis. Although the signaling pathways involved in cancer are well known, the molecular mechanisms underlying CSC actions require further investigation. In the present study, a population of colon CSCs with a cluster of differentiation 133 (CD133) surface-expression phenotype from the human SW480 colon adenocarcinoma cell line were isolated by flow cytometry. The $\mathrm{CD}_{133^{+}}$cells exhibited increased tumor sphere-forming efficiency in vitro and increased tumorigenic potential in vivo. Furthermore, the gene expression profile of colon CSCs was investigated using gene chip technology. The results demonstrated differential gene expression between the $\mathrm{CD}_{13} 3^{+}$and CD133- subpopulations, including in relation to a number of important genes with functions in transcription control, cell cycle, karyomitosis and protein phosphorylation, including cyclin dependent kinase inhibitor 1A, cyclin B1, checkpoint
\end{abstract}

Correspondence to: Professor Bing Xiao, Guangdong Provincial Key Laboratory of Gastroenterology, Department of Gastroenterology, Nanfang Hospital, Southern Medical University, Guangzhou, Guangdong 510515, P.R. China

E-mail: fjxb@163.com

${ }^{*}$ Contributed equally

Abbreviations: CSC, cancer stem cell; NOD/SCID, non-obese diabetic/severe combined immune deficiency; RT-qPCR, reverse transcription-quantitative polymerase chain reaction; MAPK, mitogen-activated protein kinase; CRC, colorectal cancer; MACS, magnetic activated cell sorting

Key words: cancer stem cell, cluster of differentiation 133, colorectal cancer, mitogen-activated protein kinase signaling pathway, p53 signaling pathway kinase 1, cyclin dependent kinase 1 and transforming growth factor $\beta$ receptor 2 . Pathway analysis revealed that the mitogen-activated protein kinase, p53 and calcium signaling pathways, as well as other important signaling pathways, were differentially activated between $\mathrm{CD}_{133^{+}}$and CD133- cells. To the best of our knowledge, these results provide the first evidence for the gene expression profile of colon CSCs in the SW480 colon adenocarcinoma cell line. Although further studies will be required to identify the functional roles of these genes in the CSC phenotype, these observations provide the basis for future studies to elucidate the pathogenesis of colorectal cancer and to develop novel tumor-targeting therapies.

\section{Introduction}

Cancer stem cells (CSCs) account for a small proportion of cancer cells and exhibit characteristics of self-renewal and tumorigenicity $(1,2)$. CSCs have been demonstrated to serve a vital role in malignant behaviors, including cancer infiltration, invasion, metastasis, and resistance to radiotherapy and chemotherapy (3-6). CSCs have been identified in numerous human cancer types, including breast, colorectal (CRC), prostate, lung, pancreatic, liver, gallbladder and renal cancer, as well as in melanoma and glioma. Therefore, numerous studies have been focused on CSCs (7-14).

The isolation of CSCs is based on the expression of putative stem cell markers or the side population in a number of solid tumors types, including breast cancer, brain tumors and colorectal cancer $(15,16)$. Identified CSC markers include cluster of differentiation 133 (CD133), CD44, CD34, aldehyde dehydrogenase (ALDH), ATP binding cassette subfamily $\mathrm{F}$ member 2 (ABCG2), C-kit and CD26 (12,17-30). CD133 is a $120-\mathrm{kDa}$ molecule with five transmembrane domains (31). Although the physiological function of CD133 remains unknown, it is considered a marker of CSCs in a number of human tumor types, including pancreatic cancer, brain tumor types, hepatocellular cancer, prostate cancer and CRC. 
Since O'Brien et al (9) and Ricci-Vitiani et al (32) separated stem-like cells from tumor tissues of patients with CRC based on CD133, an increasing number of studies of colorectal CSCs have utilized this putative marker, and have provided an important prerequisite and reliable basis for the present study and follow-up research.

Although efforts have been made to characterize CSCs, the molecular pathways utilized in CSCs, as well as the mechanisms underlying therapy resistance, remain largely unknown. However, CSCs and cancer cells have been demonstrated to utilize similar signaling pathways, including Wnt, Notch, Sonic hedgehog, Bmi-1 and phosphatase and tensin homolog pathways $(33,34)$.

In the present study, $\mathrm{CD} 133^{+}$cells were sorted from the SW480 CRC cell line by magnetic activated cell sorting (MACS), and the gene expression profiles of $\mathrm{CD}_{133^{+}}$and CD133- cells were analyzed and compared using gene chip technology and associated software. The primary genes and proteins associated with the mitogen-activated protein kinase (MAPK) and p53 signaling pathways were differentially expressed in $\mathrm{CD}_{133}{ }^{+}$cells. These observations were verified by reverse transcription-quantitative polymerase chain reaction (RT-qPCR) and western blotting in vitro. Investigation of gene expression profiles will be crucial for elucidating the characteristics of colon CSCs, with potential benefits for the development of drugs and other novel therapeutic methods targeting CSCs.

\section{Materials and methods}

Ethics statement. Ethical approval for the present study was obtained from the ethics committee of Nanfang Hospital, Southern Medical University (Guangzhou, China). Written informed consent was obtained from all patients and all clinical investigations were conducted according to the principles expressed in the Declaration of Helsinki. All animal experimental procedures were conducted in strict accordance with the recommendations of the relevant national and international guidelines for the care and use of laboratory animals (35). The protocol was approved by the Committee on the Ethics of Animal Experiments of the Department of Laboratory Animal Science, Southern Medical University. All efforts were made to minimize suffering.

Patient tissue specimens. CRC tissue fragments were obtained from 74 patients undergoing resection of colon adenocarcinoma between November 2007 and December 2010, including 45 males and 29 females. The patients were between 28-84 years old (mean age, 56 years), containing 32 cases located on the rectum, 14 cases on the sigmoid colon, 15 cases on the right colon, 9 cases on the left colon and 4 cases on the transverse colon. Written informed consent was obtained for tumor tissue collection and its use in pathological and immunohistochemical studies according to the ethical standards of the institutional review boards for human research at Nanfang Hospital, Southern Medical University and Shanxi Provincial Cancer Hospital (Taiyuan, China). Histological grade, tumor stage and tumor size were classified according to the standards of the International Union Against Cancer Tumor-Node-Metastasis classification system (36).
Tissue samples were fixed by $10 \%$ formalin for $24 \mathrm{~h}$ at $37^{\circ} \mathrm{C}$, embedded in paraffin, sliced at $5 \mu \mathrm{m}$ and stained with $0.2 \%$ hematoxylin for $3 \mathrm{~min}$ and $0.5-1 \%$ eosin for $1 \mathrm{~min}$ at $37^{\circ} \mathrm{C}$. The slices were then subjected to microscopic pathological diagnosis by two pathologists (Department of Pathology, Nanfang Hospital, Southern Medical University), who were unaware of the clinical observations.

Immunohistochemical study. Immunohistochemical staining for CD133 staining was performed using mouse anti-CD133 antibody (cat. no. AC133; Miltenyi Biotec GmbH, Bergisch Gladbach, Germany), as described previously (37). The slides were incubated with $1 \%$ bovine serum albumin (cat. no. B2064; Sigma-Aldrich; Merck KGaA, Darmstadt, Germany) for $1 \mathrm{~h}$ at $4^{\circ} \mathrm{C}$ to block non-specific binding. Subsequently, each slide was incubated overnight at $4^{\circ} \mathrm{C}$ with anti-CD133 antibody at a dilution of 1:100, washed 3 times with PBS and then incubated with $50 \mu 1$ horseradish peroxidase-labeled goat anti-mouse IgG (cat. no. TA130004; 1:100; Origene Technologies, Inc., Beijing, China) for $2 \mathrm{~h}$ at room temperature. The results of immunohistochemical CD133 expression were interpreted by Fromowitz semi-quantitative method (38). The intensity of staining and the percentage of staining positive cells was recorded in 10 high power fields, and the combination of the two methods were used to score, as follows: 0 , negative $(-) ; 1-2$, positive $(+/++) ; 3$, strong positive (+++). A BX40 Optical microscope (magnification, x200; Olympus Corporation, Tokyo, Japan) and MODEL5410 Research Grade Inverted Universal Material Fluorescent Microscope (Carl Zeiss AG, Oberkochen, Germany) were used.

Cell culture. The human CRC cell lines SW480, SW620, LoVo, HCT116, HT29 and Colo205 (American Type Culture Collection, Manassas, VA, USA) were cultured in RPMI-1640 (Hyclone; GE Healthcare Life Sciences, Logan, UT, USA) supplemented with $10 \%$ fetal bovine serum (FBS; Gibco; Thermo Fisher Scientific, Inc., Waltham, MA, USA), 100 U/ml penicillin $\mathrm{G}$, and $100 \mu \mathrm{g} / \mathrm{ml}$ streptomycin (Gibco; Thermo Fisher Scientific, Inc.). All cells were maintained at $37^{\circ} \mathrm{C}$ in a humidified $5 \% \mathrm{CO}_{2}$ incubator.

$\mathrm{CD}_{133}{ }^{+} \mathrm{SW} 480$ cells were selected by MACS using a CD133 Isolation kit (Miltenyi Biotec GmbH). This was conducted by centrifuging the cell suspension $(300 \mathrm{x} g$ for $10 \mathrm{~min}$ at room temperature), aspirating the supernatant completely and resuspending the cell pellet in $60 \mu \mathrm{l}$ sorting buffer (containing 0.01 M PBS and $2 \mathrm{mM}$ ethylenediamine tetraacetic acid) per $1 \times 10^{7}$ total cells. Subsequently, $20 \mu 1$ FcR Blocking reagent and $20 \mu \mathrm{l}$ CD133 MicroBeads-Tumor Tissue (Miltenyi Biotec $\mathrm{GmbH}$ ) was added per $1 \times 10^{7}$ total cells. Following this, the cells were mixed well and incubated for $15 \mathrm{~min}$ in a refrigerator $\left(2-8^{\circ} \mathrm{C}\right)$ under slow, continuous rotation using a MACSmix Tube Rotator. The cells were washed twice with sorting buffer and the supernatant was aspirated completely. Following this, magnetic separation was conducted. The cell suspension is loaded onto a MACS Column, which is placed in the magnetic field of a MACS Separator. The magnetically labeled $\mathrm{CD} 133^{+}$cells are retained within the column. The unlabeled cells run through; this cell fraction is thus depleted of CD133+ cells. After removing the 
column from the magnetic field, the magnetically retained $\mathrm{CD}_{133^{+}}$cells can be eluted as the positively selected cell fraction. To increase the purity, the positively selected cell fraction containing the $\mathrm{CD} 133^{+}$cells must be separated over a second column. MACS Column or MACS Separator were selected for use according to the number of total cells and the number of $\mathrm{CD}_{133^{+}}$cells. The enriched population of $\mathrm{CD} 133^{+}$cells was then suspended in serum-free culture system/medium, which contained Dulbecco's modified Eagle's medium/F12 (cat. no. SH30023.01; Hyclone; GE Healthcare Life Sciences), B27 (dilution 1:50; cat. no. 17504-044; Invitrogen; Thermo Fisher Scientific, Inc.), F12 EGF (20 ng/ml; cat. no. E5306; Sigma-Aldrich; Merck KGaA) and bFGF (10 ng/ml; cat. no. 233-FB-025; R\&D Systems, Inc., Minneapolis, MN, USA).

Flow cytometry assay. CD133 protein expression on the cell membrane was analyzed by flow cytometry in the 6 human CRC cell lines, in the logarithmic growth phase. Cells were digested with $0.25 \%$ trypsin and $1 \mathrm{mM}$ EDTA. Following incubation with $10 \mu \mathrm{l} \mathrm{FcR} \mathrm{blocking} \mathrm{reagent}$ for $10 \mathrm{~min}$ at $4^{\circ} \mathrm{C}$ (dilution, 1:50; cat. no. 130-092-575; Miltenyi Biotec $\mathrm{GmbH}$ ), to reduce unwanted binding of antibody to $\mathrm{Fc}$ receptor-expressing cell, tumor cells were washed twice by washing buffer (containing 0.01 M PBS, $0.5 \%$ bovine serum albumin and $2 \mathrm{mM}$ ethylenediamine tetraacetic acid) and resuspended at a concentration of $1 \times 10^{6}$ cells $/ \mathrm{ml}$. Subsequently, CD133/2-PE antibody (dilution, 1:50; cat. no. 130-112-315; Miltenyi Biotec GmbH) was added, mixed well and incubated for $10 \mathrm{~min}$ in the dark at $4^{\circ} \mathrm{C}$. The CD133/2-PE antibody dilution for labeling of cells and subsequent analysis by flow cytometry was $1: 50$ for $1 \times 10^{6}$ cells $/ 100 \mu$. Cell membrane CD133 protein expression was detected with a flow cytometer. Anti-IgG1 antibody ( $4^{\circ} \mathrm{C}$ for $10 \mathrm{~min}$; dilution 1:50; cat. no. 130-117-098; Miltenyi Biotec $\mathrm{GmbH}$ ) was utilized as a negative control. Data were acquired and analyzed using the FlowJo 10.0 software (FlowJo LLC, Ashland, OR, USA).

MACS. CD133+ and $\mathrm{CD}^{+} 33^{-}$cells were separated by MACS using a CD133 Isolation kit, according to the manufacturer's protocols. After adding $10 \mu \mathrm{l} \mathrm{FcR} \mathrm{(dilution,} \mathrm{1:50)} \mathrm{blocking}$ reagent per $1 \times 10^{8}$ total cells at $37^{\circ} \mathrm{C}$ for $15 \mathrm{~min}$, cells were immediately incubated with CD133/1-PE antibody (dilution 1:50; cat. no. 130-110-962; Miltenyi Biotec $\mathrm{GmbH}$ ) directly labeled with supermagnetic microbeads for $30 \mathrm{~min}$ at $4-8^{\circ} \mathrm{C}$. The cells were then washed by adding 1-2 $\mathrm{ml}$ separation buffer and centrifuged at $300 \mathrm{x}$ g for $10 \mathrm{~min}$ at $4-8^{\circ} \mathrm{C}$. The pellet was resuspended in $500 \mu 1$ separation buffer and processed to final separation using a Mini-MACs Separator Column (Miltenyi Biotec $\mathrm{GmbH}$ ). Positively-labeled $\mathrm{CD} 133^{+}$cells were flushed with $2 \mathrm{ml}$ separation buffer (containing $0.01 \mathrm{M}$ PBS and $2 \mathrm{mM}$ ethylenediamine tetraacetic acid) using a plunger fitted to the column, centrifuged for $5 \mathrm{~min}$ at $300 \mathrm{xg}$ at $4-8^{\circ} \mathrm{C}$, and washed with washing buffer. Cell numbers and viability were determined using a hemocytometer with the standard trypan blue method (0.4\% trypan blue; Invitrogen; Thermo Fisher Scientific, Inc.) (39). To assess the sorting, selected cells were incubated with CD133/2-PE antibody and analyzed using flow cytometry as aforementioned.
Primary xenografts. Non-obese diabetic/severe combined immune deficiency (NOD/SCID) mice weighing 20-25 g ( $\mathrm{n}=5$; male; 10-12 weeks old) were purchased from the Laboratory Animal Center at Southern Medical University (Guangzhou, China) and used to evaluate the tumorigenesis of $\mathrm{CD} 133^{+}$and CD133- SW480 cells sorted by MACS in vivo. Mice were allowed to acclimatize for 1 week after arrival. All animals were maintained in a sterile environment with a daily $12 / 12 \mathrm{~h}$ light/dark cycle, the ambient temperature was maintained at $20-26^{\circ} \mathrm{C}$ and the relative humidity ass $40-70 \%$. All animals were fed with relatively stable full-price nutritional feed and sterilized drinking water, which was added and replaced 3-4 times a week. After resuspension in $100 \mu \mathrm{l}$ PBS, CD133 ${ }^{+}$ and CD133- SW480 cells $\left(1 \times 10^{4}\right.$ cells $\left./ \mathrm{ml}\right)$ were mixed with $100 \mu 1$ Matrigel (Becton, Dickinson and Company, Franklin Lakes, NJ, USA) and injected subcutaneously into the left and right abdominal walls, respectively ( $\mathrm{n}=5$ mice). Tumor volume was observed weekly for 5 weeks. All animal experiments were conducted in strict accordance with the National Institute of Health Guide for the Care and Use of Laboratory Animals (35).

RNA extraction and gene microarray analysis. Total RNA was extracted from $\mathrm{CD}_{133^{+}}$and $\mathrm{CD} 133^{-}$cells sorted from SW480 cells by MACS using TRIzol ${ }^{\circledR}$ reagent (Invitrogen; Thermo Fisher Scientific, Inc.). The quality and quantity of total RNA were estimated using a NanoDrop 2000c spectrophotometer (Thermo Fisher Scientific, Inc.). An aliquot of 500 ng total RNA was reverse transcribed into cDNA using a PrimeScript ${ }^{\circledR}$ RT reagent kit (cat. no. DRR037A; Takara Bio, Inc., Otsu, Japan).

Microarray analysis was performed according to the standard protocol (40) provided by CapitalBio Technology, Inc. (Beijing, China). cDNA labeled with a fluorescent dye (Cy5 and Cy3-dCTP) was prepared with the Eberwine's linear RNA amplification method (41) and subsequent enzymatic reaction. As a measure of technical replication, dye-swap experiments were performed on each of the biological samples. Arrays were scanned with a LuxScan 10KA dual channel laser scanner (CapitalBio Technology, Inc.) and the images obtained were then analyzed using LuxScan $^{\mathrm{TM}} 3.0$ software (CapitalBio Technology, Inc.). Space-and intensity-dependent normalization based on the LOWESS program was employed $(42,43)$. Statistical analysis of Pathway (https://www.kegg.jp/) and Gene Ontology (GO) terms was performed in the Molecular Annotation System V4.0 (http://www.capitalbio.com/lifescience/informationsystems/2572.shtml), a web client program for interactive navigation within the knowledge bases, by selecting the differentially expressed genes. Data analysis utilized Pathway and GO saliency statistics. The results demonstrated the differentially expressed pathways that were involved in significant Pathway and GO terms.

$R T-q P C R$. Total RNA was extracted from $\mathrm{CD} 133^{+}$and $\mathrm{CD} 133$ SW480 cells sorted by MACS using TRIzol reagent. cDNA synthesis was performed using a reverse transcription kit (Invitrogen; Thermo Fisher Scientific, Inc.), according to the manufacturer's protocol. RT-qPCR was performed using a SYBR $^{\circledR}$ Premix Ex Taq ${ }^{\mathrm{TM}}$ II kit (cat. no. DRR081A; Takara 
Bio, Inc.) with an ABI 7500 RT-qPCR System (Applied Biosystems; Thermo Fisher Scientific, Inc.) according to the manufacturer's protocols. The reaction condition was as follows: $95^{\circ} \mathrm{C}$ for $2 \mathrm{~min}, 95^{\circ} \mathrm{C}$ for $15 \mathrm{sec}$ and $60^{\circ} \mathrm{C}$ for $30 \mathrm{sec}$ for a total of 40 cycles. The primers used [including $p 53$, $A K T 1$, transforming growth factor $\beta$ receptor 2 (TGFBR2), ATP binding cassette subfamily B member 6 ( $A B C B 6)$, cyclin dependent kinase 1 ( $C D C 2)$, checkpoint kinase 1 ( $C H E K 1)$, cyclin dependent kinase inhibitor $1 \mathrm{~A}(C D K N 1 A)$ and cyclin $\mathrm{B} 1$ $(C C N B 1)]$ are listed in Table I. Expression levels of the GAPDH were used for normalization and quantification of gene expression $2^{-\Delta \Delta \mathrm{Cq}}$ levels (44).

Protein extraction and western blotting. Total protein was purified from $\mathrm{CD}_{133^{+}}$and CD133- SW480 cells sorted by MACS. Following adding radioimmunoprecipitation lysis buffer (containing 0.01 M PBS and $2 \mathrm{mM}$ ethylenediamine tetraacetic acid), samples were centrifuged at $12,000 \mathrm{x} \mathrm{g}$ for $20 \mathrm{~min}$ at $4^{\circ} \mathrm{C}$. Protein concentrations in the supernatants were measured using a bicinchoninic acid assay kit (Pierce; Thermo Fisher Scientific, Inc.), according to the manufacturer's protocols. Western blotting was performed by electrophoresis of $30 \mu \mathrm{g}$ protein on a $10 \%$ SDS-PAGE followed by transfer to a polyvinylidene fluoride membrane (EMD Millipore, Billerica, MA, USA). The membrane was blocked by incubation in Tris-buffered saline (TBS) containing $0.1 \%$ Tween (TBS-T) and 5\% nonfat dry milk for $1 \mathrm{~h}$ at room temperature, and washed three times with TBS-T. The membranes were incubated with antibodies against extracellular signal-regulated kinase (ERK)1/2, c-Jun N-terminal kinase (JNK), p38, phosphor (p)-ERK1/2, p-p38, p-JNK (all from the same kit; cat. no. 9926), p-CDC2, p-p53, p-CHEK1, p-CHEK2, p-retinoblastoma 1 (Rb1) and p-Rb2 (all from the same kit; cat. no. 9917) (all dilutions, 1:1,000; all from Cell Signaling Technology, Inc., Danvers, MA, USA), and $\beta$-actin and $\beta$-tubulin (all dilutions, 1:200; all from Santa Cruz Biotechnology, Inc., Dallas, TX, USA) overnight at $4^{\circ} \mathrm{C}$. The blots were washed three times with TBS-T and incubated with the appropriate horseradish peroxidase-conjugated anti-rabbit IgG secondary antibodies (1:2,000; Origene Technologies, Inc.) for $1 \mathrm{~h}$ at room temperature. Following incubation with the secondary antibody, the membranes were washed again three times with TBS-T. The blots were developed by enhanced chemiluminescence (ECL) using a chemiluminescence ECL Western Blotting Detection kit reagent (BioVision, Inc., Milpitas, CA, USA) and detected using the LAS-3000 imaging system.

Statistical analysis. Statistical analysis was performed using Microsoft Office Excel 2007 (Microsoft Corporation, Redmond, WA, USA) and SPSS 13.0 statistical software (SPSS, Inc., Chicago, IL, USA). The frequencies of CD133+ expression under different features of patients were provided. In the association analysis of CD133 expression with features of patients, the $\mathrm{CD} 133^{+}$expression between two groups were compared using Mann-Whitney U-test and between multiple groups were compared using Kruskal-Wallis H-test. If the multiple groups comparison was significant, a post-hoc test using Mann-Whitney U-test with Bonferroni's P-value adjust method was performed. The expression of associated genes
Table I. Sequence of the amplification primers in the $5^{\prime}$ to $3^{\prime}$ orientation.

\begin{tabular}{ll}
\hline Gene & \multicolumn{1}{c}{ Primer (5'-3') } \\
\hline CD133 & F: GACCGACTGAGACCCAA \\
& R:TGGTTTGGCGTTGTACTCTG \\
p53 & F: ATGAGCCGCCTGAGGTTG \\
& R: AGCTGTTCCGGAGGCCCA \\
ABCG2 & F: CTGAGATCCTGAGCCTTTGG \\
& R:TGCCCATCACAACATCATCT \\
CHEK1 & F: TGTTGGATGAAAGGGATAAC \\
& R:AAACATCAACTGGTTCTGC \\
CDKN1A & F: GACTCTCAGGGTCGAAAACG \\
& R:GGATTAGGGCTTCCTCTTGG \\
CDC2 & F: AGCTGCACTCCCAATAATGA \\
& R:CGAGAGCAAATCCAAGCCAT \\
CCNB1 & F: TATGCAGCACCTGGCTAAGA \\
& R:CATGCTTCGATGTGGCATAC \\
AKT1 & F: TAGAGTGTGCGTGGCTCTCA \\
& R:CTGAATCCCGAGAGGCCAA \\
ABCB6 & F: GCACCATCCTCAAGGCTCCGGGCATC \\
& R:CCGTTCCATGGTCTGAGGCTTAGTGT \\
TGFB2 & F: AGATGGCTCGCTGAACACTACCAA \\
& R:AGAATCCTGCTGCCTCTGGTCTTT \\
& F: AAGGACTCATGACCACAGT \\
& R:CCATCACGCCACAGTTTCC \\
&
\end{tabular}

F, forward primer; R, reverse primer; CD133, cluster of differentiation 133; ABCB6, ATP-binding cassette subfamily B member 6; CDC2, cyclin dependent kinase 1; CHEK1, checkpoint kinase 1; $\mathrm{Rb} 1$, retinoblastoma 1; CDKN1A, cyclin dependent kinase inhibitor $1 \mathrm{~A}$; CCNB1, cyclin B1; TGFBR2, transforming growth factor $\beta$ receptor 2 .

and proteins in $\mathrm{CD} 133^{+}(+/++/+++)$and CD133- cell groups were compared using two independent samples Student's $\mathrm{t}$-tests. Two-sided $\mathrm{P}<0.05$ was considered to indicate a statistically significant difference.

\section{Results}

High CD133 expression is associated with disease progression in $C R C$. Previous studies on the biological importance of CSCs identified human CD133 as a representative marker for CSCs $(5,9,24,25)$. Although previous studies reported that CD133 expression was associated with lymph node metastasis (45-47), there is limited knowledge regarding other clinical outcomes associated with high-CD133-expressing CRCs. Therefore, CD133 expression levels in CRC tissues from 74 patients were examined by immunohistochemistry. CD133 protein was overexpressed in 25 tissues (33.8\%) and exhibited reduced expression in para-cancerous tissues (Fig. 1A-F). Consistent with previous results, CD133 overexpression was not significantly associated with age, sex, 

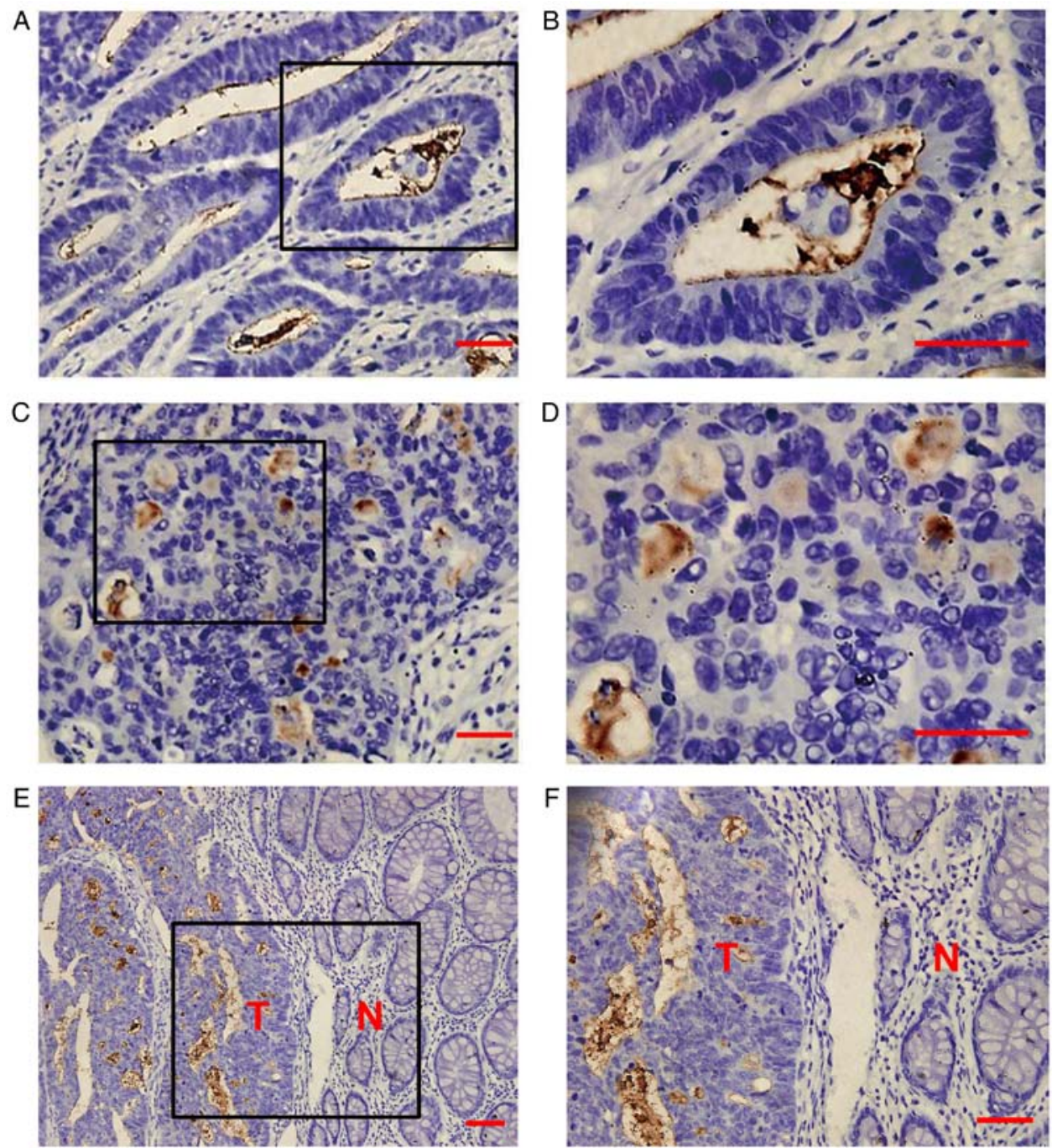

Figure 1. Representative profiles of immunostaining for CD133 in CRC tissues. CD133 expression was detected by immunohistochemistry. CD133 expression in well-differentiated CRC tissues at (A) x200 and (B) x400 magnification. CD133 expression in poorly differentiated CRC tissues at (C) x200 and (D) x400 magnification. Different levels of CD133 expression in CRC tissues and para-cancerous tissues at (E) x100 and (F) x200 magnification. Scale bar, $50 \mu \mathrm{m}$. T, cancer tissues; N, para-cancerous tissues; CRC, colorectal cancer; CD133, cluster of differentiation 133.

location or classification, but CD133 expression was significantly increased in patients with poorly differentiated tumors $(\mathrm{P}=0.021)$ and distant metastasis $(\mathrm{P}=0.007)$. The patients were further divided into those with lower stage (no lymph node involvement or distant metastasis) and higher stage (presence of lymph node and/or distant metastasis) tumors, and it was demonstrated that $\mathrm{CD} 133$ overexpression was also significantly associated with tumor stage $(\mathrm{P}=0.018)$. These results indicated that CD133 overexpression is associated with disease progression in CRC (Table II).

Isolated $\mathrm{CD} 133^{+}$cells exhibit stem-like features in vitro. The CSCs obtained from CRC cell lines were characterized by selection in serum-free culture system. Previous studies demonstrated that $\mathrm{CD} 133$ is an appropriate marker for detecting colon CSCs in primary tumor and cancer cell lines (32-37). Therefore, the percentage of $\mathrm{CD}_{133^{+}}$cells was assessed using flow cytometry. The proportions of CD133 ${ }^{+}$ cells were increased in SW480, SW620 and LoVo cell lines, compared with the other three cell lines examined, with the highest proportion $(9.16 \%)$ in SW480 cells (Fig. 2A). CD133+ and CD133 cells were then purified from SW480 cells by MACS using a CD133 Isolation kit. The purity of $\mathrm{CD} 133^{+}$cells after the first separation was $\sim 30 \%$, but this increased substantially to $>80 \%$ following the second separation (Fig. 2B). The enriched population of $\mathrm{CD} 133^{+}$cells was then suspended in serum-free culture system and grown as single cells, compared with CD133 cells (Fig. 2C and D). Subsequently the molecular features of colon CSCs were investigated by examining the expression of genes involved in stem cell-associated pathways by RT-qPCR in $\mathrm{CD}_{133^{+}}$and $\mathrm{CD} 133^{-}$populations.

$\mathrm{CD}_{133^{+}}$cells obtained from CRC cell lines have been reported to be able to proliferate as sphere-like cellular aggregates in serum-free stem cell medium (32). Therefore, the enriched population of $\mathrm{CD}_{133^{+}}$cells was suspended in serum-free culture system and grown as single cells. In the first 2-3 days of culture, the majority of the cells began to proliferate, while a number of the cells died, and cell debris was observed at the bottom of the Petri dishes. On the 5th day, the cells continued to grow and formed tumor spheres with bright refraction and round shapes, but cell shapes or cell-cell boundaries could not be accurately distinguished. Once the 
Table II. Association of CD133 expression with features of patients with colorectal cancer ( $\mathrm{n}=74)$.

\begin{tabular}{|c|c|c|c|c|c|c|}
\hline \multirow[b]{2}{*}{ Clinicopathological feature } & \multirow[b]{2}{*}{$\mathrm{n}$} & \multicolumn{3}{|c|}{$\mathrm{CD}_{133^{+}}$} & \multirow[b]{2}{*}{$\chi^{2}$ or $Z$ value } & \multirow[b]{2}{*}{ P-value } \\
\hline & & - & $+/++$ & +++ & & \\
\hline Sex & 74 & & & & -1.546 & $0.122^{\mathrm{a}}$ \\
\hline Male & 45 & 33 & 8 & 4 & & \\
\hline Female & 29 & 16 & 9 & 4 & & \\
\hline Age (years) & & & & & 0.026 & $0.872^{\mathrm{a}}$ \\
\hline$\leq 60$ & 38 & 26 & 9 & 3 & & \\
\hline$>60$ & 36 & 24 & 7 & 5 & & \\
\hline Localization & & & & & 2.967 & $0.563^{\mathrm{b}}$ \\
\hline Rectum & 32 & 19 & 9 & 4 & & \\
\hline Sigmoid colon & 14 & 11 & 3 & 0 & & \\
\hline Right colon & 15 & 10 & 3 & 2 & & \\
\hline Left colon & 9 & 7 & 2 & 0 & & \\
\hline Transverse colon & 4 & 2 & 2 & 0 & & \\
\hline Classification & & & & & -1.398 & $0.162^{\mathrm{a}}$ \\
\hline Adenocarcinoma & 66 & 42 & 16 & 8 & & \\
\hline Mucinous adenocarcinoma & 8 & 7 & 1 & 0 & & \\
\hline Grade & & & & & 7.683 & $0.021^{\mathrm{c}}$ \\
\hline High & 13 & 11 & 2 & 0 & & \\
\hline Moderate & 36 & 24 & 9 & 3 & & \\
\hline Low & 17 & 7 & 5 & 5 & & \\
\hline TNM stage & & & & & 10.115 & $0.018^{\mathrm{b}}$ \\
\hline I & 13 & 11 & 2 & 0 & & \\
\hline IIA+IIB & 30 & 18 & 10 & 2 & & \\
\hline IIIA+IIIB+IIIC & 21 & 17 & 1 & 3 & & \\
\hline IV & 10 & 3 & 4 & 3 & & \\
\hline Distal metastasis & & & & & -2.719 & $0.007^{\mathrm{a}}$ \\
\hline Positive & 10 & 3 & 4 & 3 & & \\
\hline Negative & 64 & 46 & 13 & 5 & & \\
\hline
\end{tabular}

Cancer stage was determined according to the AJCC Cancer Staging Manual 7th edition (36). ${ }^{\mathrm{a} M a n n-W h i t n e y ~ U ~ t e s t ; ~}{ }^{\mathrm{b}}$ Kruskal-Wallis test; ${ }^{\mathrm{c}}$ Mucinous adenocarcinoma was not included. CD133, cluster of differentiation 133; TNM, Tumor-Node-Metastasis (36).

size of the spheres reached $75-100 \mu \mathrm{m}$, they could be passaged. As the passage number increased, it was observed that the size of the tumor spheres remained relatively unchanged while their shape became more spherical (Fig. 2E-G). In the serum-free culture system, CRC stem cells were gradually enriched. In order to make the visual field clearer, enriched CRC stem cells were inoculated into a 96-well plate and to ensure that there was a single sphere in each field of view. The spheres were then imaged and their entire growth process was observed. CD133+ cells re-cultured in serum-containing medium adhered to the dish walls and formed a monolayer. These results demonstrated that $\mathrm{CD}_{133}{ }^{+} \mathrm{SW} 480$ cells possessed stem/progenitor cell-like properties, including differentiation capacity.

$\mathrm{CD} \mathrm{H3}^{+}$cells possess increased tumorigenic potential in vivo. Additionally, whether $\mathrm{CD} 133^{+}$colon cells were more tumorigenic than their CD133- counterparts in vivo was also investigated. Each NOD/SCID mouse was injected subcutaneously in the left and right abdominal walls with $1 \times 10^{4} \mathrm{CD} 133^{+}$ and CD133 cells, respectively. Tumors were detected in the left abdominal wall of NOD/SCID mice 2 weeks after subcutaneous injection of $\mathrm{CD}_{133^{+}}$cells, but no tumors in the right wall (Fig. 3A and B). The tumors were $>1 \mathrm{~cm}^{3}$ after 3-4 weeks. Transplanted tumors were confirmed as colon cancer by hematoxylin and eosin staining (Fig. 3C and D). These results demonstrated that $\mathrm{CD}_{133^{+}}$cells possessed increased tumorigenic capacity, compared with $\mathrm{CD} 133^{-}$cells.

Gene expression profiles in colon CSCs. Potential genes associated with the distinct cellular behaviors of the two cell populations were identified by generating gene expression profiles of $\mathrm{CD} 133^{+}$and $\mathrm{CD}^{-} 33^{-}$SW480 cells using a $22 \mathrm{~K}$ Human Genome Array. A total of 21,522 genes were detected and 414 differentially expressed genes were observed, of which 185 were upregulated and 229 were downregulated in $\mathrm{CD}_{133^{+}}$cells (Fig. 4A). These genes included $B M I 1$, which was previously reported to be involved in regulating tumor growth and the epithelial-mesenchymal 

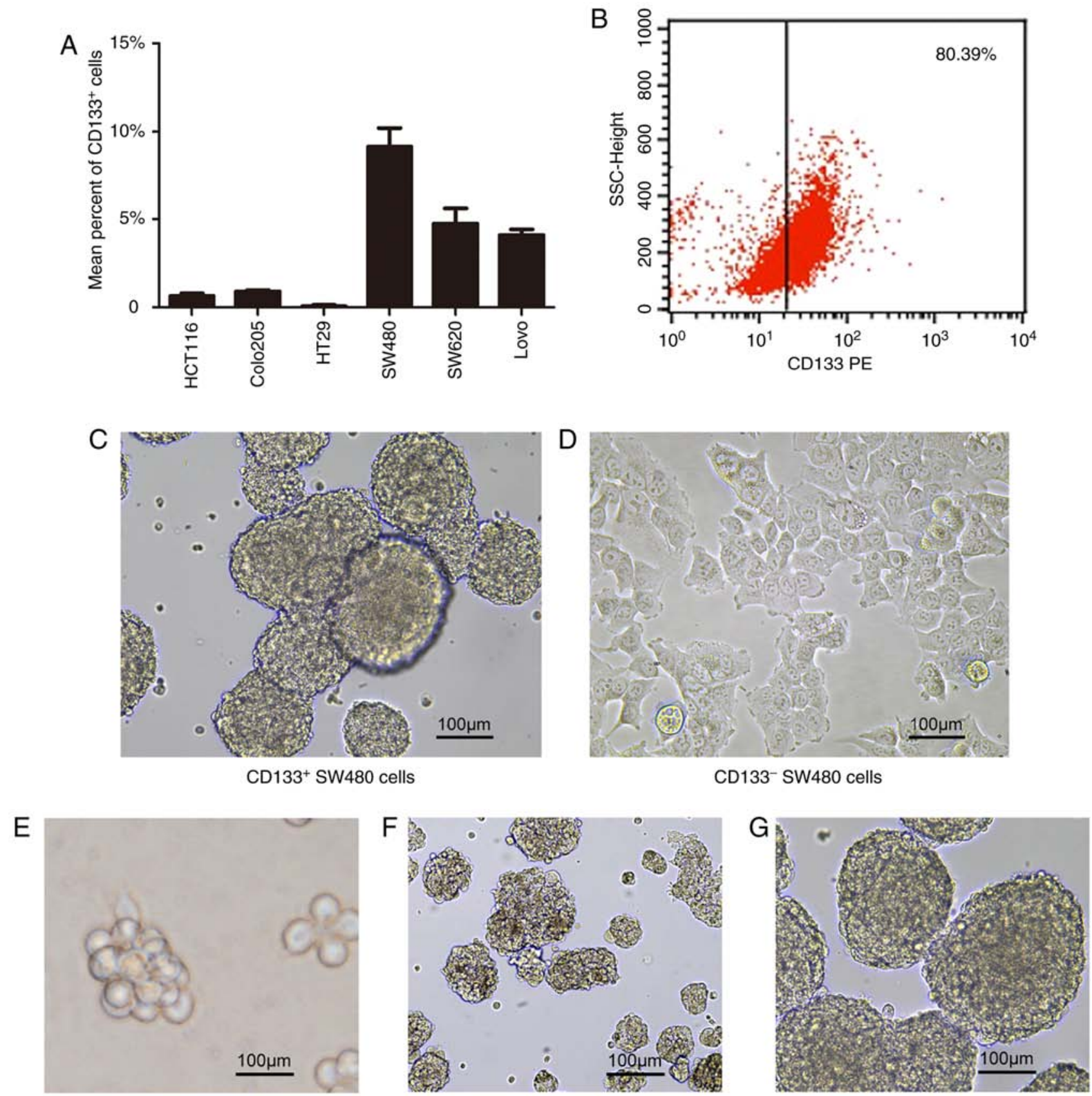

Figure 2. Isolated CD133+ cells exhibit stem-like features in vitro. (A) Analysis of the proportion of $\mathrm{CD}^{+} 33^{+}$cells in 6 different CRC cell lines by flow cytometry. The proportion of $\mathrm{CD}_{133^{+}}$cells was highest in the SW480 cell line at $9.16 \%$. (B) Purity of $\mathrm{CD} 133^{+} \mathrm{CRC}$ cells after the second separation was evaluated by flow cytometry. (C) CD133 ${ }^{+}$CRC cells isolated by MACS formed suspended spheres. (D) Tumorsphere results from CD133- CRC cells isolated by MACS (E) The enriched population of $\mathrm{CD} 133^{+}$cells was suspended in serum-free medium and grown as single cells. In the first 2-3 days of culture, the majority of the cells began to proliferate. (F) On the 5th day, cells continued to grow and formed tumor spheres with bright refraction and round shapes. (G) When the size of the spheres reached 75-100 $\mu \mathrm{m}$, they could be passaged. As the passage number increased, the size of the tumor spheres were observed to remain relatively unchanged, while the cells became more spherical in appearance. MACS, magnetic activated cell sorting; CRC, colorectal cancer; CD133, cluster of differentiation 133.

transition process (48). A number of $A B C$ transporters were also upregulated in $\mathrm{CD} 133^{+}$cells, including $\mathrm{ABC}$ subfamily B member $6(A B C B 6), A B C C 2, A B C A 7$ and $A B C F 3$, which may be associated with drug resistance in colorectal CSCs. Furthermore, the expression levels of anti-apoptosis genes, including interferon regulatory factor-3 (IRF-3), IRF-7 and death associated protein kinase 3 , were increased in $\mathrm{CD} 133^{+}$ cells, compared with CD133- cells. Therefore, it was considered that the anti-apoptotic effect of colorectal CSCs was exerted by activating or inhibiting particular cell signaling pathways. These genes may be relevant to the malignant behavior of colorectal CSCs.

The differentially expressed genes associated with biological processes in $\mathrm{CD} 133^{+}$and $\mathrm{CD} 133^{-}$cell samples accounted for $55.6 \%$, including transcriptional regulation, cell cycle, mitosis, transcription, cell division and protein amino acid phosphorylation. The differentially expressed genes associated with cell composition accounted for $16.1 \%$, including nuclear, cytoplasm, cytosol, cell membrane, cell membrane integrity, cytoplasmic membrane and mitochondrial composition. The 
A
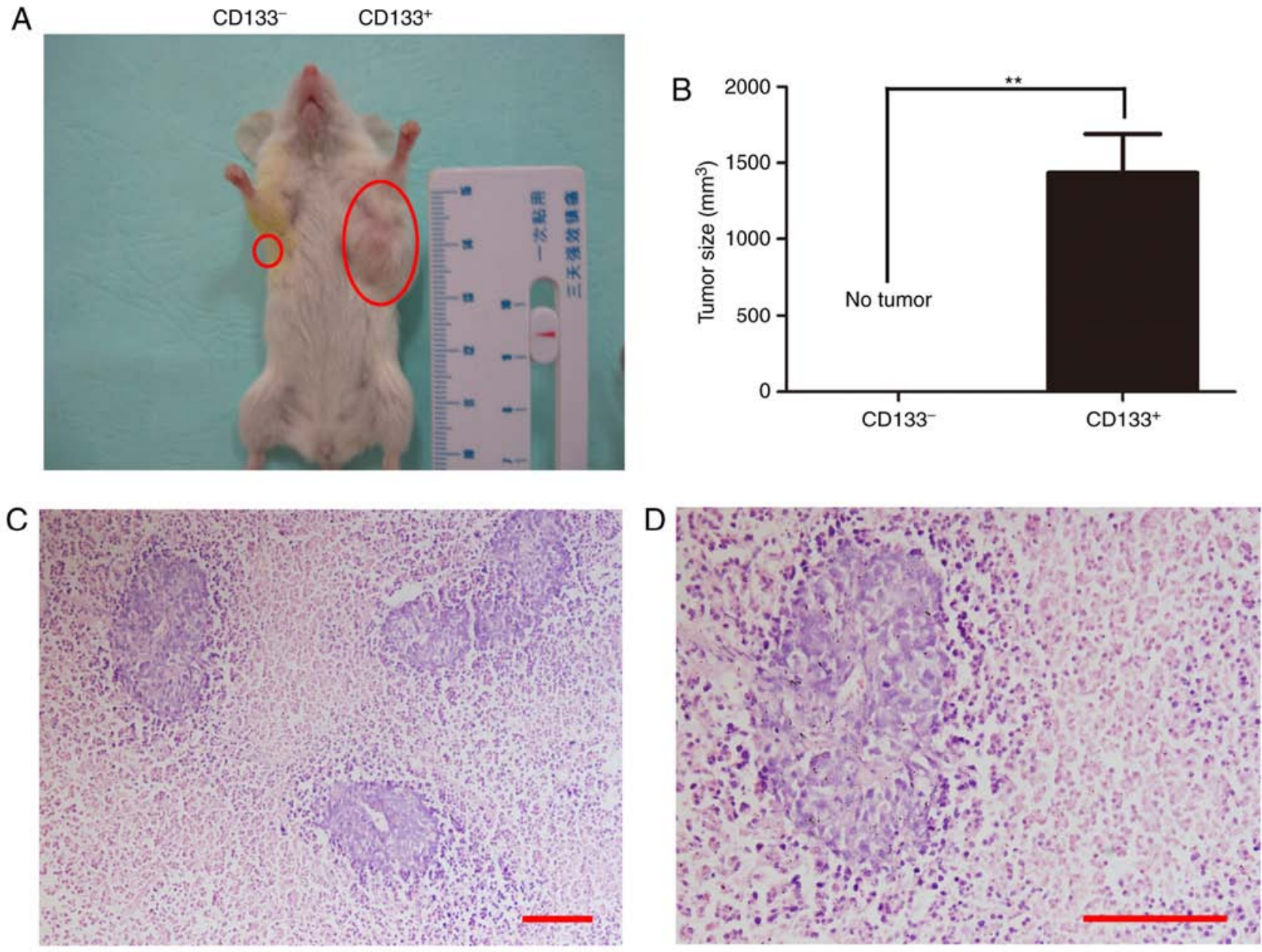

Figure 3. CD133+ cells exhibit increased tumorigenic potential in vivo. (A) Image of a representative mouse captured 4 weeks after cell transplantation. (B) Analysis of tumor size with two sorted cell groups at 4 weeks post-injection. Tumors in the left abdominal wall of non-obese diabetic/severe combined immune deficiency mice were $>1 \mathrm{~cm}^{3}$, but no tumors were observed in the right wall $(\mathrm{n}=5)$. Data are presented as the mean \pm standard deviation. ${ }^{* *} \mathrm{P}<0.01$. (C and D) Grafts of the CD133+ cells were excised 4 weeks after transplantation and stained with hematoxylin and eosin and depicted at (C) $\mathrm{x} 200$ and (D) x400 magnifications. CD133, cluster of differentiation 133

differentially expressed genes associated with molecular function accounted for $28.3 \%$, including protein binding, nucleic acid binding, transferase activity, ATP binding, zinc ion binding, GTP binding and transcription factor activity. GO analysis demonstrated that the differentially expressed genes were primarily distributed in the cellular process $(14.7 \%)$, the physiological process $(13.2 \%)$, the metabolism $(7.10 \%)$, the biological regulation $(6.80 \%)$, and the regulation of biological processes $(6.22 \%)$, cells $(5.38 \%)$, binding $(4.51 \%)$, developmental processes $(4.20 \%)$, catalytic activity $(4.20 \%)$ and other functions.

Gene pathway analysis revealed that the differentially expressed genes were distributed in multiple pathways, including the cell cycle, p53, tight junction, glioma, calcium, insulin, proteasome, gonadotropin-releasing hormone and MAPK signaling pathways (Table III). A total of 6 differentially expressed genes associated with the MAPK signaling pathway and 6 differentially expressed genes associated with the p53 signaling pathway were identified. Therefore, it was hypothesized that CD133 regulation of CRC occurrence and development may be associated with the MAPK and p53 signaling pathways. To examine this hypothesis, the expression levels of representative genes were examined by RT-qPCR to verify the results of the cDNA gene chip analysis. The mRNA levels of $p 53, A K T 1, T G F B R 2$ and $A B C B 6$ were significantly increased in $\mathrm{CD}_{133}{ }^{+}$cells, compared with $\mathrm{CD} 133$ - cells $(\mathrm{P}<0.05$; Fig. 4B), while the mRNA levels of $C D C 2, C H E K 1, C D K N 1 A$ and $C C N B 1$ were significantly downregulated in $\mathrm{CD} 133^{+}$cells $(\mathrm{P}<0.05$; Fig. 4B). These results were consistent with the gene chip results (with the exception of CHEK1 mRNA), indicating that the microarray results were generally reliable. Subsequently, the protein expression levels of these key molecules were examined by western blotting. There were no significant difference in ERK1/2, p38, JNK and p-JNK protein expression levels between $\mathrm{CD}_{133^{+}}$and CD133- cells. However, expression levels of p-ERK1/2 and p-p38 proteins were increased in CD133 ${ }^{+}$ cells, compared with CD133- cells (Fig. 4C). Furthermore, all the phosphorylated proteins involved in the p53 signaling pathway, including p-p53, p-CDC2, p-CHEK1 (Ser345), p-CHEK2 (Tyr68), p-Rb (Ser795) and p-Rb (Ser807/811), had reduced expression in $\mathrm{CD}_{133^{+}}$cells, compared with $\mathrm{CD} 133$ cells (Fig. 4D and E). These results indicated that CD133 may assist CRCs to invade and metastasize by activating the MAPK signaling pathway and inhibiting the p53 signaling pathway. 
Table III. Pathways associated with differential genes.

\begin{tabular}{lcccl}
\hline Name & Total & P-value & Q-value & \multicolumn{1}{c}{ Gene } \\
\hline Cell cycle & 9 & $6.53 \times 10^{-9}$ & $1.2 \times 10^{-5}$ & $\begin{array}{l}\text { CDKN1A, YWHAQ, CCNB1, CHEK1, YWHAG, CCNA2, } \\
\text { PCNA, E2F2 and CDC2 }\end{array}$ \\
p53 signaling pathway & 6 & $1.01 \times 10^{-6}$ & $1.44 \times 10^{-4}$ & CDKN1A, CCNB1, CHEK1, PMAIP1, CCNG1 and CDC2 \\
Tight junction & 7 & $4.36 \times 10^{-6}$ & $3.40 \times 10^{-5}$ & MAGI1, TJP3, AKT1, SPTAN1, PRKCZ, RRAS2 and LLGL2 \\
Glioma & 5 & $1.53 \times 10^{-05}$ & $9.58 \times 10^{-5}$ & CDKN, CALM1, AKT1, E2F2 and CALM2 \\
$\begin{array}{l}\text { Pancreatic cancer } \\
\text { Calcium signaling pathway }\end{array}$ & 5 & $2.56 \times 10^{-5}$ & $1.56 \times 10^{-4}$ & TGFBR2, AKT1, ERBB2, RALBP1 and E2F2 \\
& 7 & $7.65 \times 10^{-4}$ & $3.11 \times 10^{-5}$ & GNA11, VDAC2, CALM1, ERBB2, LTB4R2, CALM2 and \\
Insulin signaling pathway & 6 & $5.53 \times 10^{-5}$ & $2.78 \times 10^{-4}$ & EIF4E, EXOC7, CALM1, AKT1, PRKCZ and CALM2 \\
Prostate cancer & 5 & $6.63 \times 10^{-5}$ & $3.26 \times 10^{-4}$ & CDKN1A, AKT1, ERBB2, E2 and KLK3 \\
$\begin{array}{l}\text { Proteasome } \\
\text { GnRH signaling pathway }\end{array}$ & 5 & $8.24 \times 10^{-5}$ & $3.72 \times 10^{-4}$ & PSMA1, PSMD14, PSMB7 and PSMD6 \\
MAPK signaling pathway & 7 & $1.67 \times 10^{-4}$ & $6.00 \times 10^{-4}$ & GNA11, CALM1, PLA2G4B, JMJD7-PLA2G 4B and CALM2 \\
& & $3.74 \times 10^{-4}$ & $1.10 \times 10^{-3}$ & TGFBR2,AKT1,PLA2G4B, JMJD7-PLA2G4B,CACNA2D2, \\
& & & RRAS2 and RAP1A
\end{tabular}

MAPK, mitogen-activated protein kinase; CDKN1A, cyclin-dependent kinase 1A; YWHAQ, tyrosine 3-monooxygenase-tryptophan 5-minoxygenase activation protein $\theta$; YWHAG, tyrosine 3-monooxygenase/tryptophan 5-monooxygenase activation protein $\gamma$; CCNB1, cyclin B1; CHEK1, checkpoint kinase 1; PCNA, proliferating cell nuclear antigen; CDC2, cyclin dependent kinase 1; PMAIP1, phorbol-12-myristate-13-acetate-induced protein 1; MAGI1, membrane associated guanylate kinase, WW and PDZ domain containing 1; TJP3, tight junction protein 3; RRAS2, RAS related 2; LLGL2, lethal giant larvae homolog 2; CALM1, calmodulin 1; TGFBR2, transforming growth factor $\beta$ receptor 2; ERBB2, Erb-B2 receptor tyrosine kinase 2; RALBP1, RalA binding protein 1; GNA11, G protein subunit $\alpha 11$; VDAC2, voltage dependent anion channel 2; LTB4R2, leukotriene B4 receptor 2; NTSR1, neurotensin receptor 1; EIF4E, eukaryotic translation initiation factor 4E; EXOC7, exocyst complex component 7; PRKCZ, protein kinase C $\zeta$; KLK3, kallikrein related peptidase 3; PSMA1, proteasome subunit $\alpha 1$; PSMD14, proteasome 26S subunit, non-ATPase 14; PSMB7, proteasome subunit $\beta 7$; JMJD7, jumonji domain containing 7; PLA2G4B, phospholipase A2 group IVB; CACNA2D2, calcium voltage-gated channel auxiliary subunit $\alpha 2 \delta 2$.

\section{Discussion}

CD133 is known as the most frequently used surface marker for colorectal CSCs $(5,45)$. However, cell surface molecules other than CD133, including CD44, CD24, CD166, ALDH1 and epithelial cell adhesion molecule, have also been considered as putative colorectal CSCs markers $(46,47)$. Regarding the prognostic values of these markers, numerous researchers have determined CD133 to be the most clinically relevant $(37,45)$. Therefore, the clinicopathological significance of CD133 expression in CRC were examined and it was demonstrated that $\mathrm{CD} 133$ overexpression in CRC is associated with higher grade, distant metastasis and tumor stage. This indicates that overexpression of CD133 on the cell membrane may be a beneficial marker for assisting with predicting the clinical outcome of patients with CRC.

MACS purified a population of colon CSCs presenting a CD133 surface phenotype. CD133 ${ }^{+}$cells exhibited increased tumorigenic potential in vivo and increased tumor sphere-forming efficiency in vitro, compared with CD133- cells, indicating that they retained the capacities for self-renewal and differentiation.

To understand the biological properties of CSCs, gene microarray detection of colon CSCs was performed to identify potential factors involved in stemness maintenance and tumorigenic ability. The gene expression profile of $\mathrm{CD}_{133}{ }^{+} \mathrm{SW} 480$ cells differed from that of CD133 SW480 cells, with 185 genes being upregulated and 229 genes being downregulated. Analysis of the functions of the differentially expressed genes between these two cell types revealed that the main distinctions were in the biological process (55.6\%), molecular function (28.3\%) and cellular constituents (16.1\%). Further analysis demonstrated that the primary differences were associated with transcription control, cell cycle, karyomitosis and protein phosphorylation.

A number of the differentially expressed genes were associated with tumor development, including BMI1, CHEK1, TGFBR2, AKT1, CDKN1A, CCNB1 and ABCB6. BMI1, as a member of the polycomb protein family, was upregulated in $\mathrm{CD}_{133^{+}}$cells. BMI1 was reportedly overexpressed in glioblastoma and sustained the self-renewal of malignant glioma and mammary stem cells $(48,49)$, while inhibition of BMI1 resulted in growth arrest of pre-established tumors in vivo. However, the exact roles of BMI1 in the normal colon and in CRC are unclear. It was hypothesized that overexpression of BMI1 may represent a possible molecular mechanism for repairing DNA damage in colorectal CSCs. These results indicated that BMI1 may be a relevant therapeutic target in CRC.

$A$ number of $A B C$ transporters were also upregulated in $\mathrm{CD}_{133^{+}}$cells, including $\mathrm{ABCB} 6, \mathrm{ABCC} 2, \mathrm{ABCA7}$ and $\mathrm{ABCF} 3$. Multidrug resistance is known to be the most important mechanism underlying drug resistance and is another characteristic of CSCs (50). However, ABCG2, which is differentially expressed in numerous tumor types, as well as other genes associated with tumor occurrence, including CHEK1, TGFBR2, AKT1, CDKN1A and CCNB1, were not overexpressed in $\mathrm{CD}_{133^{+}}$cells.

The present results of gene microarray analysis indicated that the MAPK and $\mathrm{p} 53$ signaling pathways were notably altered 
A
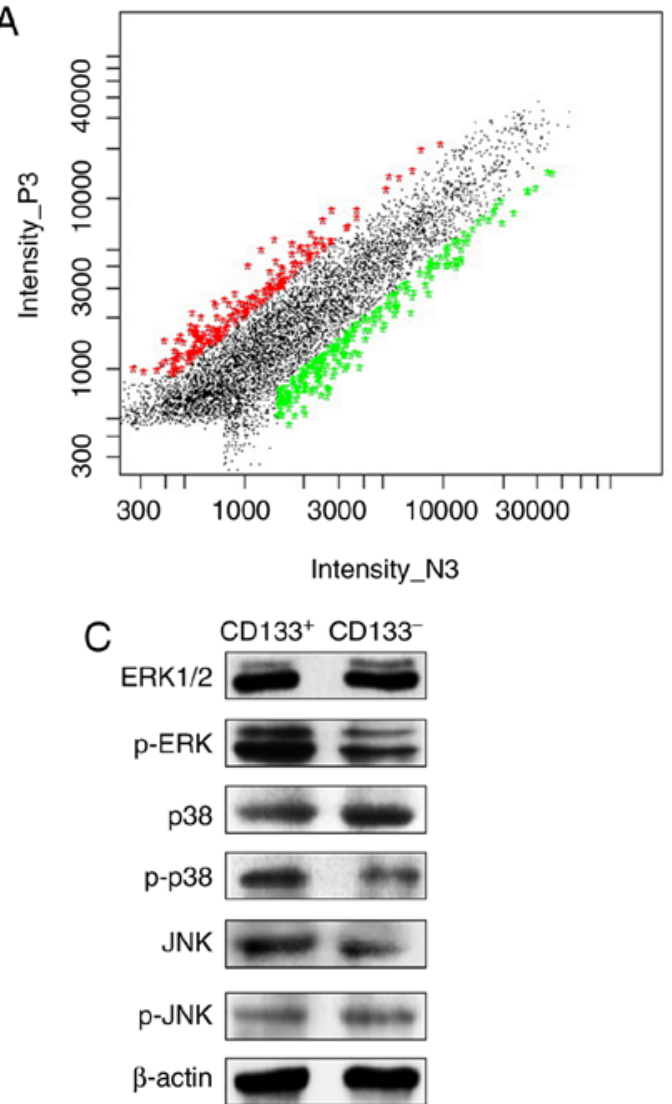

D

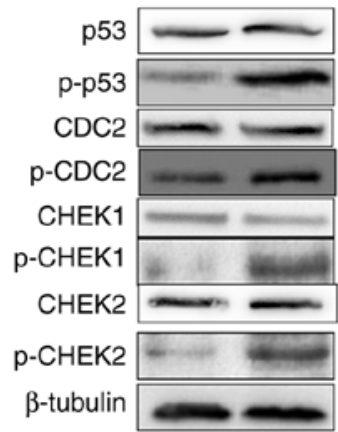

E

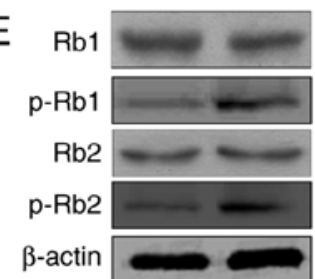

B
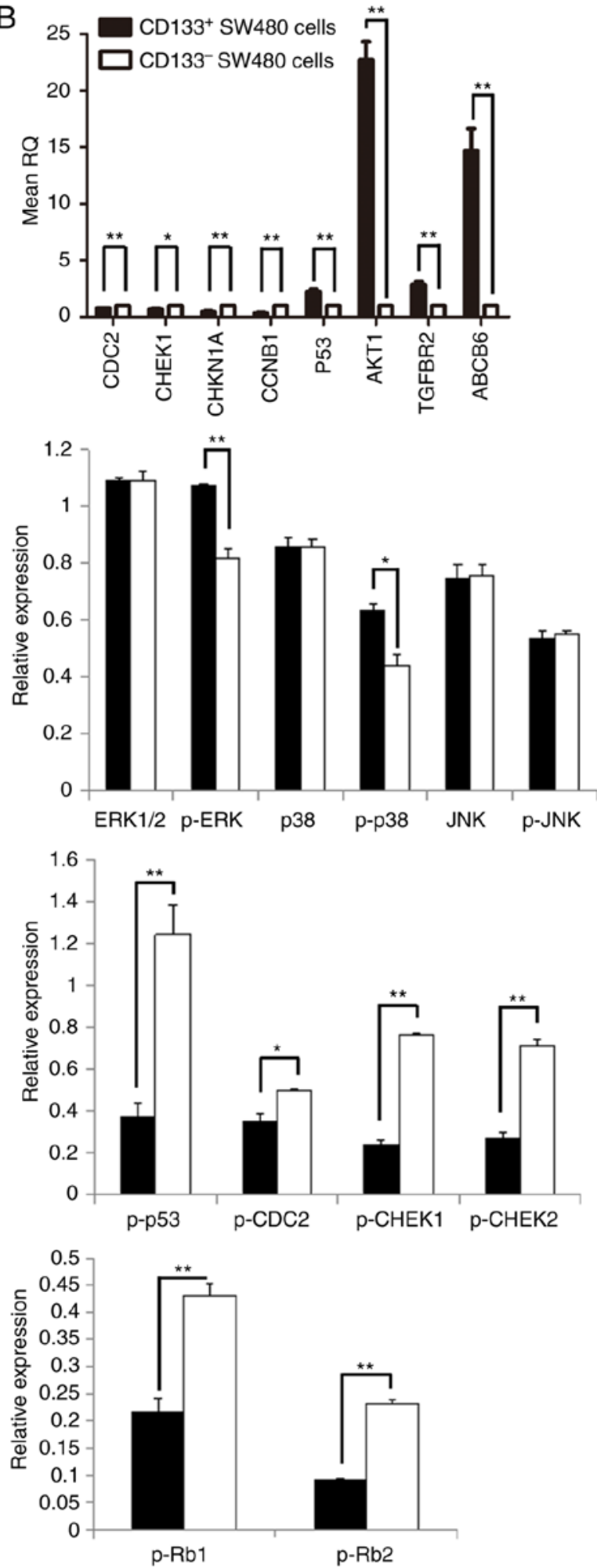

Figure 4. Gene expression profiles in colon cancer stem cells. (A) Log-log scatter plot of global complementary DNA scanning. The gene expression profile of the two types of cells was examined using the $22 \mathrm{~K}$ Human Genome Array. (B) Gene expression in colorectal CD133+ and CD133- SW480 cells. (C) Expression of proteins associated with the mitogen-activated protein kinase signaling pathway. (D) Expression of proteins associated with the p53 signaling pathway. (E) Expression of proteins $\mathrm{p}-\mathrm{Rb}(\mathrm{Ser} 795)$ and $\mathrm{p}-\mathrm{Rb}(\mathrm{Ser} 807 / 811)(\mathrm{n}=3)$. Data are presented as means \pm standard deviations. ${ }^{*} \mathrm{P}<0.05$ and ${ }^{* * *} \mathrm{P}<0.01$. CD133, cluster of differentiation 133; p-, phospho-; ERK, extracellular signal-regulated kinase; JNK, c-Jun N-terminal kinase; CDC2, cyclin dependent kinase 1; CHEK1, checkpoint kinase 1; Rb1, retinoblastoma 1; CDKN1A, cyclin dependent kinase inhibitor 1A; CCNB1, cyclin B1; TGFBR2, transforming growth factor $\beta$ receptor 2; ABCB6, ATP-binding cassette subfamily B member 6 .

in $\mathrm{CD} 133^{+}$SW480 cells. A total of 8 genes associated with the MAPK and 553 signaling pathways were detected by RT-qPCR and also identified by gene microarray, except for CHEK1. The
MAPK pathway comprises the primary signaling pathway for cell proliferation, and previous studies demonstrated that the activated MAPK signaling pathway serves active roles 
in cell adhesion, vasculogenesis, invasion and metastasis in CRC (51). For example, Fang and Richardson (52) reported that activated MAPK was associated with the occurrence of colon cancer, while Sunayama et al (53) confirmed that the MAPK kinase 1/ERK and phosphoinositide 3-kinase/mechanistic target of rapamycin pathways were associated with maintenance of the self-renewal and tumorigenic capacities of glioblastoma CSCs. The present results demonstrated that p-ERK1/2 and p-p38 were upregulated in CD133+ cells. These results indicated that the MAPK signaling pathway may be activated in colorectal CSCs, and that ERK and p38 may serve important roles in the proliferation of colorectal CSCs.

p53 is a known tumor suppressor gene with a key role in the cellular response to stress, which acts as a major obstructer of tumorigenesis. Post-translational modification of p53 by phosphorylation may be an important mechanism underlying p53 stabilization and function (54-56). Therefore, p53 was also tested as an accepted cancer suppressor gene in the present study. p-p53, p-CDC2, p-CHEK1 (Ser68), p-CHEK2 (Tyr68), p-Rb (Ser795), and p-Rb (Ser808/811), which are all associated with the p53 signaling pathway (57), were all downregulated in colorectal CSCs. Therefore, it was hypothesized that the p53 signaling pathway may be inhibited in colorectal CSCs. p53 activity is primarily modulated by phosphorylation at different sites, and a number of upstream kinases are involved in this process (58). Melnikova et al (59) determined that ERK1/2 and MAPK were physically associated with mutant p53 in the nucleus, and phosphorylation of mutant p53 on serine 15 depended on the level of ERK1/2 activation. Cordenonsi et al (60) also reported that receptor tyrosine kinase/Ras/MAPK pathway activity induced p53 N-terminal phosphorylation. Therefore, it was indicated that activation of the MAPK signaling pathway may be associated with inhibition of the p53 signaling pathway.

In conclusion, CD133 ${ }^{+} \mathrm{SW} 480$ cells exhibit increased colony-forming ability and invasive capacity, compared with CD133- cells, in vitro and in vivo. The present observations further confirmed that CD133 was a CSC surface marker. By analyzing gene expression profiles, genes that were differentially expressed in CSCs were identified, which may therefore be involved in CSC properties. Numerous genes identified in the present study may also be potential CSC marker candidates, and their evaluation could thus increase the specificity of CSC identification. Although further studies are required to identify the functional roles of these genes in the CSC phenotype and their association with the CD133 oncogenic mechanism, the present observations provide a basis for potential future approaches to clarifying the mechanisms of CRC and for developing novel tumor-targeting therapies.

\section{Acknowledgements}

The authors would like to thank the staff of the Pathology Departments of Nanfang Hospital, Southern Medical University (Guangzhou, China) and Shanxi Provincial Cancer Hospital (Taiyuan, China) for assisting with immunohistochemistry data acquisition. Additionally, the authors would like to thank the Center Laboratory of Southern Medical University (Guangzhou, China) for supplying numerous experimental instruments and equipment.

\section{Funding}

The present study was supported by the National Natural Science Foundation of China (grant no. 81603477), the Special Science Foundation for Innovation and Development of Universities of Guangdong Province (grant no. C1032224) and the Science and Technology Planning Project of Guangdong Province (grant no. 2015A030302023).

\section{Availability of data and materials}

All data generated or analyzed during this study are included in this published article.

\section{Authors' contributions}

BX made contributions to conception and design. YW and LZ conducted the majority of the experiments, analyzed the data and wrote the manuscript. QQ, YL and LL were responsible for animal experiments and cell culture in this experiment. $\mathrm{XD}$ was involved in the colorectal cancer stem cell selection and data analysis. All authors reviewed and approved the final manuscript.

\section{Ethics approval and consent to participate}

Ethical approval for the present study was obtained from the ethics committee of Nanfang Hospital, Southern Medical University (Guangzhou, China). Written informed consent was obtained from all patients and all clinical investigations were conducted according to the principles expressed in the Declaration of Helsinki. All animal experimental procedures were conducted in strict accordance with the recommendations of the relevant national and international guidelines for the care and use of laboratory animals. The protocol was approved by the Committee on the Ethics of Animal Experiments of the Department of Laboratory Animal Science, Southern Medical University.

\section{Patient consent for publication}

All patients consented for publication.

\section{Competing interests}

The authors declare that they have no competing interests.

\section{References}

1. Reya T, Morrison SJ, Clarke MF and Weissman IL: Stem cells, cancer, and cancer stem cells. Nature 414: 105-111, 2001.

2. Sánchez Alvarado A and Yamanaka S: Rethinking differentiation: Stem cells, regeneration, and plasticity. Cell 157: 110-119, 2014.

3. Sottoriva A, Verhoeff JJ, Borovski T, McWeeney SK, Naumov L, Medema JP, Sloot PM and Vermeulen L: Cancer stem cell tumor model reveals invasive morphology and increased phenotypical heterogeneity. Cancer Res 70: 46-56, 2010.

4. Yu Y, Ramena G and Elble RC: The role of cancer stem cells in relapse of solid tumors. Front Biosci (Elite Ed) 4: 1528-1541, 2012.

5. Zeuner A, Todaro M, Stassi G and De Maria R: Colorectal cancer stem cells: From the crypt to the clinic. Cell Stem Cell 15: 692-705, 2014.

6. Pattabiraman DR and Weinberg RA: Tackling the cancer stem cells-what challenges do they pose? Nat Rev Drug Discov 13: 497-512, 2014. 
7. Al-Hajj M, Wicha MS, Benito-Hernandez A, Morrison SJ and Clarke MF: Prospective identification of tumorigenic breast cancer cells. Proc Natl Acad Sci USA 100: 3983-3988, 2003.

8. Choi SA, Lee JY, Phi JH, Wang KC, Park CK, Park SH and Kim SK: Identification of brain tumour initiating cells using the stem cell marker aldehyde dehydrogenase. Eur J Cancer 50: 137-149, 2014.

9. O'Brien CA, Pollett A, Gallinger S and Dick JE: A human colon cancer cell capable of initiating tumour growth in immunodeficient mice. Nature 445: 106-110, 2007.

10. Collins AT, Berry PA, Hyde C, Stower MJ and Maitland NJ: Prospective identification of tumorigenic prostate cancer stem cells. Cancer Res 65: 10946-10951, 2005.

11. Bao B, Ahmad A, Azmi AS, Ali S and Sarkar FH: Overview of cancer stem cells (CSCs) and mechanisms of their regulation: Implications for cancer therapy. Curr Protoc Pharmacol: Chapter 14: Unit 14.25, 2013.

12. Bussolati B, Bruno S, Grange C, Buttiglieri S, Deregibus MC, Cantino D and Camussi G: Isolation of renal progenitor cells from adult human kidney. Am J Pathol 166: 545-555, 2005.

13. Kim CF, Jackson EL, Woolfenden AE, Lawrence S, Babar I, Vogel S, Crowley D, Bronson RT and Jacks T: Identification of bronchioalveolar stem cells in normal lung and lung cancer. Cell 121: 823-835, 2005.

14. Fang D, Nguyen TK, Leishear K, Finko R, Kulp AN, Hotz S, Van Belle PA, Xu X, Elder DE and Herlyn M: A tumorigenic subpopulation with stem cell properties in melanomas. Cancer Res 65: 9328-9337, 2005.

15. Hoshi N, Kusakabe T, Taylor BJ and Kimura S: Side population cells in the mouse thyroid exhibit stem/progenitor cell-like characteristics. Endocrinology 148: 4251-4258, 2007.

16. Kato K, Takao T, Kuboyama A, Tanaka Y, Ohgami T, Yamaguchi S, Adachi S, Yoneda T, Ueoka Y, Kato K, et al: Endometrial cancer side-population cells show prominent migration and have a potential to differentiate into the mesenchymal cell lineage. Am J Pathol 176: 381-392, 2010.

17. Lapidot T, Sirard C, Vormoor J, Murdoch B, Hoang T, Caceres-Cortes J, Minden M, Paterson B, Caligiuri MA and Dick JE: A cell initiating human acute myeloid leukaemia after transplantation into SCID mice. Nature 367: 645-648, 1994.

18. Ginestier C, Hur MH, Charafe-Jauffret E, Monville F, Dutcher J, Brown M, Jacquemier J, Viens P, Kleer CG, Liu S, et al: ALDH1 is a marker of normal and malignant human mammary stem cells and a predictor of poor clinical outcome. Cell Stem Cell 1: 555-567, 2007.

19. Singh SK, Hawkins C, Clarke ID, Squire JA, Bayani J, Hide T, Henkelman RM, Cusimano MD and Dirks PB: Identification of human brain tumour initiating cells. Nature 432: 396-401, 2004.

20. Suetsugu A, Nagaki M, Aoki H, Motohashi T, Kunisada T and Moriwaki H: Characterization of $\mathrm{CD}_{133^{+}}$hepatocellular carcinoma cells as cancer stem/progenitor cells. Biochem Biophys Res Commun 351: 820-824, 2006.

21. Li C, Heidt DG, Dalerba P, Burant CF, Zhang L, Adsay V, Wicha M, Clarke MF and Simeone DM: Identification of pancreatic cancer stem cells. Cancer Res 67: 1030-1037, 2007.

22. Su J, Xu XH, Huang Q, Lu MQ, Li DJ, Xue F, Yi F, Ren JH and Wu YP: Identification of cancer stem-like CD44+ cells in human nasopharyngeal carcinoma cell line. Arch Med Res 42: 15-21, 2011.

23. Prince ME, Sivanandan R, Kaczorowski A, Wolf GT, Kaplan MJ, Dalerba P, Weissman IL, Clarke MF and Ailles LE: Identification of a subpopulation of cells with cancer stem cell properties in head and neck squamous cell carcinoma. Proc Natl Acad Sci USA 104: 973-978, 2007.

24. Zhou L, Wei X, Cheng L, Tian J and Jiang JJ: CD133, one of the markers of cancer stem cells in Hep-2 cell line. Laryngoscope 117 455-460, 2007

25. Shi C, Tian R, Wang M, Wang X, Jiang J, Zhang Z, Li X, He Z, Gong W and Qin R: CD $44^{+} \mathrm{CD} 133^{+}$population exhibits cance stem cell-like characteristics in human gallbladder carcinoma. Cancer Biol Ther 10: 1182-1190, 2010.

26. Landen CN Jr, Goodman B, Katre AA, Steg AD, Nick AM, Stone RL, Miller LD, Mejia PV, Jennings NB, Gershenson DM, et al: Targeting aldehyde dehydrogenase cancer stem cells in ovarian cancer. Mol Cancer Ther 9 3186-3199, 2010

27. Cui F, Wang J, Chen D and Chen YJ: CD133 is a temporary marker of cancer stem cells in small cell lung cancer, but not in non-small cell lung cancer. Oncol Rep 25: 701-708, 2011.
28. Liang D and Shi Y: Aldehyde dehydrogenase-1 is a specific marker for stem cells in human lung adenocarcinoma. Med Oncol 29: 633-639, 2012.

29. Prud'homme GJ: Cancer stem cells and novel targets for antitumor strategies. Curr Pharm Des 18: 2838-2849, 2012.

30. Pang R, Law WL, Chu AC, Poon JT, Lam CS, Chow AK, Ng L, Cheung LW, Lan XR, Lan HY, et al: A subpopulation of CD26 cancer stem cells with metastatic capacity in human colorectal cancer. Cell Stem Cell 6: 603-615, 2010

31. Miraglia S, Godfrey W, Yin AH, Atkins K, Warnke R, Holden JT, Bray RA, Waller EK and Buck DW: A novel five-transmembrane hematopoietic stem cell antigen: Isolation, characterization, and molecular cloning. Blood 90: 5013-5021, 1997.

32. Ricci-Vitiani L, Lombardi DG, Pilozzi E, Biffoni M, Todaro M, Peschle C and De Maria R: Identification and expansion of human colon-cancer-initiating cells. Nature 445: 111-115, 2007.

33. Pardal R, Clarke MF and Morrison SJ: Applying the principles of stem-cell biology to cancer. Nat Rev Cancer 3: 895-902, 2003.

34. Dong HJ, Jang GB, Lee HY, Park SR, Kim JY, Nam JS and Hong IS: The Wnt $/ \beta$-catenin signaling/Id 2 cascade mediates the effects of hypoxia on the hierarchy of colorectal-cancer stem cells. Sci Rep 6: 22966, 2016.

35. Turner PV, Pekow C, Clark JM, Vergara P, Bayne K, White WJ, Kurosawa TM, Seok SH and Baneux P: Roles of the international council for laboratory animal science (ICLAS) and international association of colleges of laboratory animal medicine (IACLAM) in the global organization and support of 3Rs advances in laboratory animal science. J Am Assoc Lab Anim Sci 54: 174-180, 2015.

36. Edge SB, Byrd DR, Compton CC, Fritz AG, Greene FL and Trotti A (eds.): AJCC Cancer Staging Manual. 7th edition. Springer, New York, NY, 2010.

37. Kojima M, Ishii G, Atsumi N, Fujii S, Saito N and Ochiai A: Immunohistochemical detection of CD133 expression in colorectal cancer: A clinicopathological study. Cancer Sci 99: 1578-1583, 2008

38. Fromowitz FB, Viola MV, Chao S, Oravez S, Mishriki Y, Finkel G, Grimson R and Lundy J: ras p21 expression in the progression of breast cancer. Hum Pathol 18: 1268-1275, 1987.

39. Louis KS and Siegel AC: Cell viability analysis using trypan blue: Manual and automated methods. Methods Mol Biol 740: 7-12, 2011.

40. Guo Y, Guo H, Zhang L, Xie H, Zhao X, Wang F, Li Z, Wang Y, Ma S, Tao J, et al: Genomic analysis of anti-hepatitis B virus (HBV) activity by small interfering RNA and lamivudine in stable HBV-producing cells. J Virol 79: 14392-14403, 2005.

41. Phillips J and Eberwine JH: Antisense RNA amplification: A linear amplification method for analyzing the mRNA population from single living cells. Methods 10: 283-288, 1996.

42. MAQC Consortium, Shi L, Reid LH, Jones WD, Shippy R, Warrington JA, Baker SC, Collins PJ, de Longueville F, Kawasaki ES, et al: The MicroArray Quality Control (MAQC) project shows inter- and intraplatform reproducibility of gene expression measurements. Nat Biotechnol 24: 1151-1161, 2006.

43. Patterson TA, Lobenhofer EK, Fulmer-Smentek SB, Collins PJ, Chu TM, Bao W, Fang H, Kawasaki ES, Hager J, Tikhonova IR, et al: Performance comparison of one-color and two-color platforms within the MicroArray Quality Control (MAQC) project. Nat Biotechnol 24: 1140-1150, 2006.

44. Livak KJ and Schmittgen TD: Analysis of relative gene expression data using real-time quantitative PCR and the 2(-Delta Delta C(T)) method. Methods 25: 402-408, 2001.

45. Horst D, Kriegl L, Engel J, Kirchner T and Jung A: CD133 expression is an independent prognostic marker for low survival in colorectal cancer. Br J Cancer 99: 1285-1289, 2008.

46. Mărgaritescu C, Pirici D, Cherciu I, Bărbălan A, Cârtână T and Săftoiu A: CD133/CD166/Ki-67 triple immunofluorescence assessment for putative cancer stem cells in colon carcinoma. J Gastrointestin Liver Dis 23: 161-170, 2014.

47. Lugli A, Iezzi G, Hostettler I, Muraro MG, Mele V, Tornillo L, Carafa V, Spagnoli G, Terracciano L and Zlobec I: Prognostic impact of the expression of putative cancer stem cell markers CD133, CD166, CD44s, EpCAM, and ALDH1 in colorectal cancer. Br J Cancer 103: 382-390, 2010.

48. Tu Y, Gao X, Li G, Fu H, Cui D, Liu H, Jin W and Zhang Y: MicroRNA-218 inhibits glioma invasion, migration, proliferation, and cancer stem-like cell self-renewal by targeting the polycomb group gene Bmi1. Cancer Res 73: 6046-6055, 2013. 
49. Liu S, Dontu G, Mantle ID, Patel S, Ahn NS, Jackson KW, Suri $\mathrm{P}$ and Wicha MS: Hedgehog signaling and Bmi-1 regulate self-renewal of normal and malignant human mammary stem cells. Cancer Res 66: 6063-6071, 2006.

50. de Jonge-Peeters SD, Kuipers F, de Vries EG and Vellenga E: $\mathrm{ABC}$ transporter expression in hematopoietic stem cells and the role in AML drug resistance. Crit Rev Oncol Hematol 62: 214-226, 2007.

51. Blaj C, Schmidt EM, Lamprecht S, Hermeking H, Jung A, Kirchner T and Horst D: Oncogenic effects of High MAPK activity in colorectal cancer mark progenitor cells and persis irrespective of RAS mutations. Cancer Res 77: 1763-1774, 2017.

52. Fang JY and Richardson BC: The MAPK signalling pathways and colorectal cancer. Lancet Oncol 6: 322-327, 2005.

53. Sunayama J, Matsuda K, Sato A, Tachibana K, Suzuki K, Narita Y, Shibui S, Sakurada K, Kayama T, Tomiyama A and Kitanaka C: Crosstalk between the PI3K/mTOR and MEK/ERK pathways involved in the maintenance of self-renewal and tumorigenicity of glioblastoma stem-like cells. Stem Cells 28: 1930-1939, 2010.

54. Belle JI, Petrov JC, Langlais D, Robert F, Cencic R, Shen S, Pelletier J, Gros P and Nijnik A: Repression of p53-target gene Bbc3/PUMA by MYSM1 is essential for the survival of hematopoietic multipotent progenitors and contributes to stem cell maintenance. Cell Death Differ 23: 759-775, 2016.
55. Vogelstein B, Lane D and Levine AJ: Surfing the p53 network. Nature 408: 307-310, 2000.

56. Li XL, Zhou J, Chen ZR and Chng WJ: P53 mutations in colorectal cancer-molecular pathogenesis and pharmacological reactivation. World J Gastroenterol 21: 84-93, 2015.

57. Vogelstein B and Kinzler KW: Cancer genes and the pathways they control. Nat Med 10: 789-799, 2004.

58. Fuchs B, O'Connor D, Fallis L, Scheidtmann KH and Lu X p53 phosphorylation mutants retain transcription activity. Oncogene 10: 789-793, 1995.

59. Melnikova VO, Santamaria AB, Bolshakov SV and Ananthaswamy HN: Mutant p53 is constitutively phosphorylated at Serine 15 in UV-induced mouse skin tumors: Involvement of ERK1/2 MAP kinase. Oncogene 22: 5958-5966, 2003.

60. Cordenonsi M, Montagner M, Adorno M, Zacchigna L, Martello G, Mamidi A, Soligo S, Dupont S and Piccolo S: Integration of TGF-beta and Ras/MAPK signaling through p53 phosphorylation. Science 315: 840-843, 2007. 